\title{
Numeric and volumetric changes in Leydig cells during aging of rats ${ }^{1}$
}

Bruno Vinicius Duarte Neves', Fernando Lorenzini", Djanira Veronez"I', Eduardo Pereira de Miranda'v, Gabriela Duarte Nevesv , Rogério de Fragavı

'Fellow Master degree, Postgraduate Program in Surgical Clinic, Department of Urology, Universidade Federal University do Paraná (UFPR), Curitiba-PR, Brazil. Scientific, intellectual, conception and design of the study; acquisition, analysis and interpretation of data; technical procedures; histopathological examinations; statistics analysis; manuscript preparation; critical revision.

"PhD, Department of Urology, School of Medicine, UFPR, Curitiba-PR, Brazil. Scientific, intellectual, conception and design of the study; critical revision.

I'PhD, Associate Professor, Department of Anatomy, School of Medicine, UFPR, Curitiba-PR, Brazil. Scientific, intellectual, conception, and design of the study; analysis and interpretation of data; histopathological examinations; critical revision.

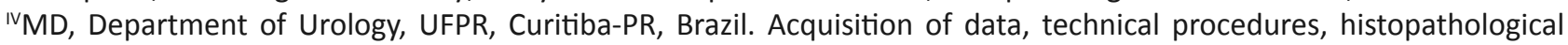
examinations, critical revision.

${ }^{\vee}$ Graduate student, School of Medicine, UNIVILLE, Joinville-SC, Brazil. Acquisition of data, technical procedures, histopathological examinations.

VIPhD, Associate Professor, Department of Urology, School of Medicine, UFPR, Curitiba-PR, Brazil. Scientific, intellectual, conception and design of the study; analysis and interpretation of data; statistical analysis; critical revision.

\section{Abstract}

Purpose: To analyze the effects of aging in rats on the nuclear volume, cytoplasmic volume, and total volume of Leydig cells, as well as their number.

Methods: Seventy-two Wistar rats were divided into six subgroups of 12 rats, which underwent right orchiectomy at $3,6,9,12,18$, and 24 months of age. The weight and volume of the resected testicles were assessed. A stereological study of Leydig cells was conducted, which included measurements of cell number and nuclear, cytoplasmic, and total cell volumes.

Results: The weight and volume of the resected testicles showed reductions with age. Only the subgroup composed of 24-month old rats showed a decrease in the nuclear volume of Leydig cells. Significant reductions in the cytoplasmic volume and total volume of Leydig cells were observed in 18- and 24-month old rats. The number of Leydig cells did not vary significantly with age.

Conclusions: Aging in rats resulted in reduction of the nuclear, cytoplasmic, and total cell volumes of Leydig cells. There was no change in the total number of these cells during aging. Key words: Aging. Leydig Cells. Testis. Hypogonadism. Testosterone. Rats. 


\section{Introduction}

A decline in gonadal function is one change that occurs in aging men ${ }^{1}$. Even in the absence of disease, testosterone (TT) produced by testicles decreases progressively with age ${ }^{2}$. This phenomenon, known as senile hypogonadism, has also been observed in rats ${ }^{3}$.

Leydig cells (LCs), first discovered in 1850 by Franz Leydig, are closely associated with production of the hormone $\mathrm{TT}^{4}$. Given their role in the production of androgens, these cells are important for differentiation and development of the male genital tract ${ }^{5}$. However, LCs suffer the deleterious effects of cell aging, and can gradually lose their capacity for TT synthesis ${ }^{6}$.

The mechanisms that cause this drop in steroidogenesis are still poorly understood ${ }^{7}$. Stereology, the histological examination of cell structures ${ }^{8}$, might facilitate a better understanding of this process. This study aims to evaluate volumetric and numeric changes in Leydig cells during aging by examining rats of different ages.

\section{- Methods}

\section{Animal husbandry and surgery}

This study followed the ethical principles established by the Brazilian College of Animal Experimentation (COBEA) and was approved by the Universidade Federal do Paraná (UFPR) Committee for Ethics in Research (number 23075.032620/2010-10).

Seventy-two male albino Wistar rats (Rattus norvegicus var. albinus) were used for the study. Relative humidity was maintained between $50 \%$ and $60 \%$, and the ambient temperature was maintained at $22^{\circ} \mathrm{C}$, with a 12-hour light/dark cycle and minimal external noise. Access to water and standard food was provided on an ad libitum basis.

The rats were divided into six groupsdesignated $\mathrm{G} 1$ to $\mathrm{G6}$ - with 12 animals in each group, which underwent orchiectomy at 3,6 , $9,12,18$ and 24 months of age, respectively.

For surgical procedures, the rats were anesthetized intraperitoneally with ketamine hydrochloride $(57.67 \mathrm{mg} / \mathrm{ml})$ and xylazine hydrochloride $(2 \% \mathrm{w} / \mathrm{v})$ at a dose of $1 \mathrm{ml} / \mathrm{kg}$ body weight. A one-punch cardiac puncture was carried out in the morning for blood sampling and induction of cardiac arrest by exsanguination. This was followed by resection of testicles, kidneys, bladder, liver, brain, heart, aorta, and penis. The right testicle was weighed on a high-precision electronic balance, and its dimensions (length, width, height) were measured with a digital caliper. The remaining organs were used in other studies.

\section{Morphometric and histological analysis}

Testicular volume was calculated using the following formula: length $\times$ width $\times$ height $\times 0.523^{9}$.

Incisions $2 \mathrm{~mm}$ in length and depth were made in the top, middle, and lower poles of the testicles, to improve penetration of the fixative ( $80 \%$ alcohol, formaldehyde, and acetic acid). The testicles were kept in the fixative solution for 16 hours, then dehydrated by passage through solutions of xylene and alcohol. Since the testicle is a non-isotropic organ, the orientator method ${ }^{10}$ was employed to obtain uniform sections. The pieces of fixed testicle were embedded in paraffin and sliced 5- $\mu \mathrm{m}$ thick using a microtome (American Optical Spencer AO 820). Three sections per blade were prepared and stained with hematoxylin and eosin (HE).

The sections were studied using a photomicroscope (Zeiss Axiophot D-7082) at $\mathrm{x} 400$ magnification. Digital images of ten 
random histological fields from each section were captured. Images were analyzed in MetaSystem VSViewer software.

\section{Stereological study of Leydig cells}

\section{Leydig cell nuclear volume (LCNV)}

To obtain the mean nuclear diameter of LCs, ten nuclear cores were overlaid with a circular contour. The following formula was used for this calculation: $L C N V=4 / 3 R^{3}$, where $\mathrm{R}=$ nuclear radius.

\section{Leydig cell cytoplasmic volume (LCCV)}

LCCV was calculated by applying the following formula: LCCV $=\%$ cytoplasm $\times$ LCNV $\%$ nucleus.

Leydig cell total volume (LCTV)

LCTV was evaluated as the sum of LCNV and LCCV, which was expressed in cubic micrometers $\left(\mu \mathrm{m}^{3}\right)$.

\section{Leydig cell absolute number (LCAN)}

LCAN, which corresponds to the numerical density $\left(N_{v}\right)$ of LCs, or the number of LCs per unit volume of testis, was estimated using the disector method ${ }^{11}$. The disectors were compiled by joining photomicrographs of ten equal microscopic fields of each histological section of the testicle. The disector method involves counting the nuclei that are observable in a reference section and not observable in a look-up section separated from the reference section by a known distance. We carried out this procedure in both directions (i.e., moving from the reference section to the look-up section and vice versa) to increase the number of disectors. Disectors were overlaid systematically and randomly to cover the area encompassing all testicle sections.

$N_{v}$ was obtained by dividing the number of disectors $\left(\Sigma Q^{-}\right)$by the sum of their volumes $\left(\sum V_{\text {dis }}\right)$, which was obtained from the product of the test area and the disector height:

$$
V_{\text {dis }}=a \times h
$$

Where $V_{\text {dis }}$ is the total volume of the disector, $a$ is the test area, and $h$ is the disector height.

Thus, $N_{v}$ can be obtained from the following formula:

$$
N_{v}=\Sigma \mathrm{Q} / \Sigma \mathrm{V}_{\text {dis }}
$$

Where $\Sigma Q^{-}$is the number of disectors and $\sum \mathrm{V}_{\text {dis }}$ is the sum of the disectors volumes.

\section{Statistical analysis}

All parameters were statistically analyzed by one-way analysis of variance (ANOVA). In cases where a significant difference between groups was indicated, the results were compared using the Student-NewmanKeuls (SNK) post-hoc test. All analyses and graphs were generated using GraphPad Prism 6 statistical software. The significance threshold was $95 \%(p<0.05)$.

\section{- Results}

There was no loss of subjects; all rats remained alive until the predetermined time at which all the members of the group were sacrificed. Figure 1 shows the morphological characteristics of the animals and Figure 2 shows the morphometric characteristics of the resected testicles. 

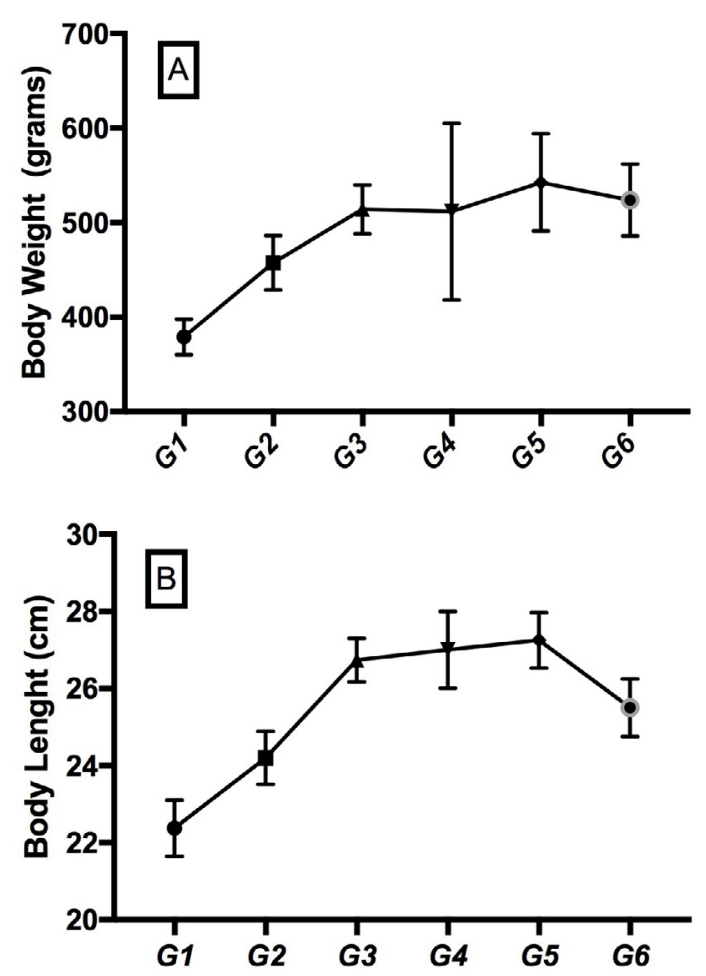

Figure 1 - A, mean body weight of rats in different age groups; B, mean body length of rats in different age groups.

LCNV was generally constant across age groups, except for G6, which exhibited a statistically significant reduction in LCNV (Figure 3 and Table 1). However, LCCV values were observed to decrease progressively as the age of the rats increased, as demonstrated in Figure 4; statistically significant differences in LCCV were found when G1 was compared with the other groups (Table 2). Consequently, LCTV also declined gradually with age (Figure 5 and Table 3). In contrast, LCAN varied minimally between the groups; no statistically significant differences were observed (Figure 6).

In Figure 7, all groups were shown. As the LC's becomes old its nuclear, cytoplasmic and total volume decrease. The last group have demonstrated significant hypotrofic findings.
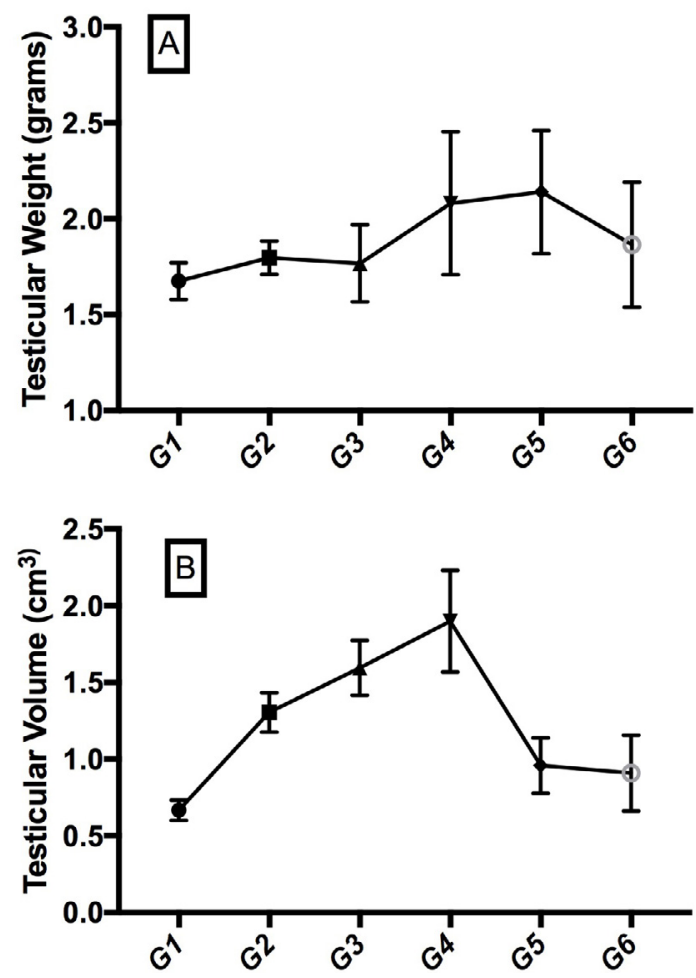

Figure 2 - A, mean testicular weight of rats in different age groups; B, mean testicular volume of rats in different age groups.

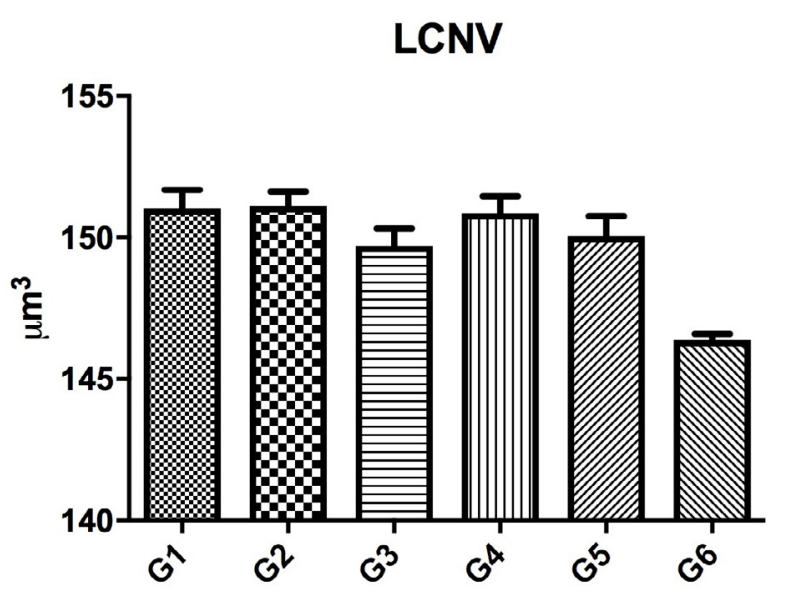

Figure 3 - Leydig cell nuclear volume (LCNV) of rats in different age groups. 
Table 1 - Comparison of mean Leydig cell nuclear volume (LCNV) between groups with different ages.

\begin{tabular}{llllll}
\hline Group & $\begin{array}{l}\text { Versus } \\
\text { Group }\end{array}$ & $\begin{array}{l}\text { Absolute } \\
\text { difference } \\
\text { between } \\
\text { groups }\end{array}$ & $\begin{array}{l}\text { Mean } \\
\text { LCNV } \\
\left(\mu \mathrm{m}^{3}\right)\end{array}$ & \pm SD \\
G1 & G2 & 0.08 & ns & 151.05 & \pm 4.36 \\
& G3 & 1.32 & ns & & \\
& G4 & 0.17 & ns & & \\
& G5 & 0.97 & ns & & \\
& G6 & 4.64 & $*$ & & \\
G2 & G3 & 1.4 & ns & 151.09 & \pm 4.33 \\
& G4 & 0.25 & ns & & \\
& G5 & 1.05 & ns & & \\
& G6 & 4.7 & $*$ & & \\
& G4 & 1.14 & ns & 149.69 & \pm 3.97 \\
G3 & G5 & 0.34 & ns & & \\
& G6 & 3.32 & $*$ & & \\
G4 & G5 & 0.79 & ns & 150.85 & \pm 4.30 \\
& G6 & 4.46 & $*$ & & \\
G5 & G6 & 3.67 & ns & 150.04 & \pm 4.21 \\
G6 & - & - & - & 146.37 & \pm 2.06 \\
\hline
\end{tabular}

$\mathrm{ns}$, not significant; * $\mathrm{p}<0.05 ; \pm \mathrm{SD}$, standart deviation; post-hoc Student-Newman-Keuls test.

\section{LCCV}

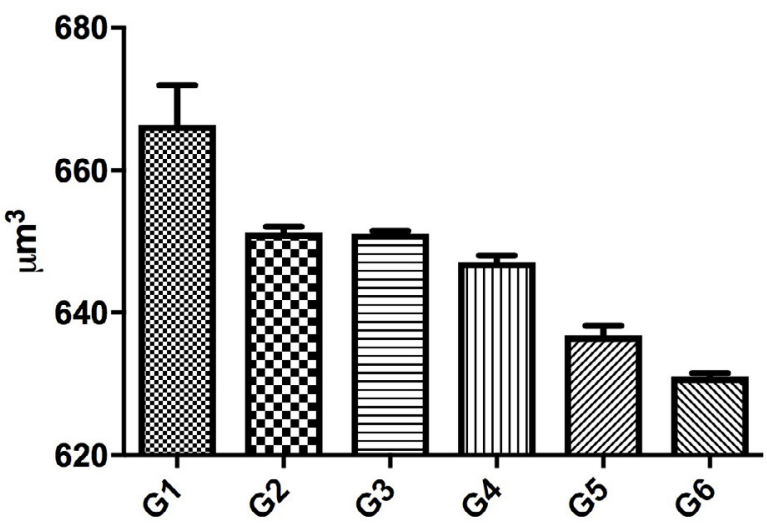

Figure 4 - Leydig cell cytoplasmic volume (LCCV) of rats in different age groups.
Table 2 - Comparison of mean Leydig cell cytoplasmic volume (LCCV) between groups with different ages.

\begin{tabular}{llllll} 
Group & $\begin{array}{l}\text { Versus } \\
\text { Group }\end{array}$ & $\begin{array}{l}\text { Absolute } \\
\text { difference } \\
\text { between } \\
\text { groups }\end{array}$ & $\begin{array}{l}\text { Mean } \\
\text { LCCV } \\
\left(\mu \mathrm{m}^{3}\right)\end{array}$ & \pm SD \\
\hline & G2 & 15.08 & $*$ & 666.36 & \pm 21.63 \\
G1 & G3 & 15.24 & $*$ & & \\
& G4 & 19.23 & $*$ & & \\
& G5 & 29.57 & $*$ & & \\
& G6 & 35.37 & $*$ & & \\
& G3 & 0.16 & ns & 651.28 & \pm 4.55 \\
G2 & G4 & 4.15 & ns & & \\
& G5 & 14.49 & $*$ & & \\
& G6 & 29.30 & $*$ & & \\
& G4 & 3.99 & ns & 651.12 & \pm 4.46 \\
& G5 & 14.33 & $*$ & & \\
G3 & G6 & 20.14 & $*$ & & \\
G4 & G5 & 10.34 & $*$ & 647.13 & \pm 4.76 \\
& G6 & 16.14 & $*$ & & \\
G5 & G6 & 5.805 & ns & 636.79 & \pm 7.31 \\
G6 & - & - & - & 630.98 & \pm 6.42 \\
\hline
\end{tabular}

ns, not significant; * $p<0.05 ; \pm S D$, standart deviation; post-hoc Student-Newman-Keuls test.

LCTV

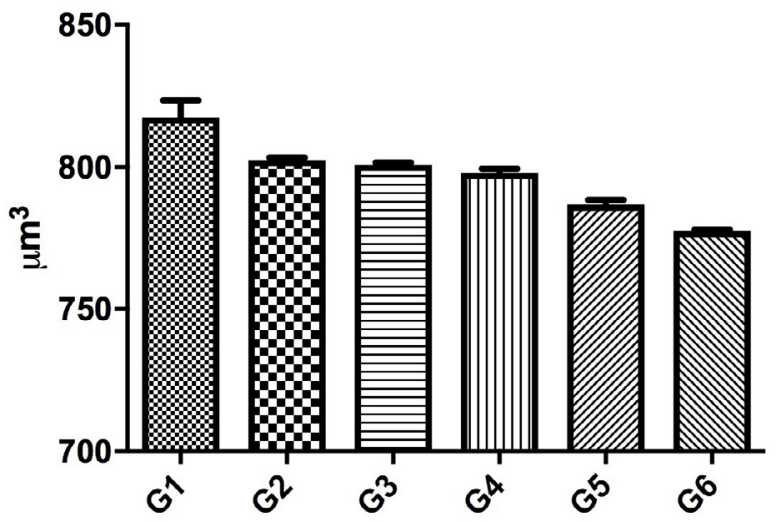

Figure $\mathbf{5}$ - Leydig cell total volume (LCTV) of rats in different age groups. 
Table 3 - Comparison of mean Leydig cell total volume (LCTV) between groups with different ages.

\begin{tabular}{|c|c|c|c|c|c|}
\hline Group & $\begin{array}{l}\text { Versus } \\
\text { Group }\end{array}$ & $\begin{array}{l}\text { Absolute } \\
\text { difference } \\
\text { between } \\
\text { groups }\end{array}$ & $\mathbf{p}$ & $\begin{array}{l}\text { Mean } \\
\text { LCTV } \\
\left(\mu \mathrm{m}^{3}\right)\end{array}$ & $\pm S D$ \\
\hline \multirow{5}{*}{ G1 } & $\mathrm{G} 2$ & 14.99 & $*$ & 817.39 & 22.9 \\
\hline & G3 & 16.56 & $*$ & & \\
\hline & G4 & 19.41 & $*$ & & \\
\hline & G5 & 30.54 & $*$ & & \\
\hline & G6 & 40.01 & $*$ & & \\
\hline \multirow{5}{*}{ G2 } & G3 & 1.56 & ns & 802.40 & 6.37 \\
\hline & G4 & 4.41 & ns & & \\
\hline & G5 & 11.13 & $*$ & & \\
\hline & G6 & 25.02 & $*$ & & \\
\hline & G4 & 2.84 & ns & 800.84 & 6.12 \\
\hline \multirow{2}{*}{ G3 } & G5 & 13.98 & $*$ & & \\
\hline & G6 & 23.46 & $*$ & & \\
\hline \multirow[t]{2}{*}{ G4 } & G5 & 11.13 & $*$ & & 7.03 \\
\hline & G6 & 20.61 & $*$ & 797.99 & \\
\hline G5 & G6 & 9.47 & $*$ & 786.85 & 8.40 \\
\hline G6 & - & - & - & 777.38 & 6.59 \\
\hline
\end{tabular}

$\mathrm{ns}$, not significant; * $\mathrm{p}<0.05 ; \pm \mathrm{SD}$, standart deviation; post-hoc Student-Newman-Keuls test.

\section{LCAN}

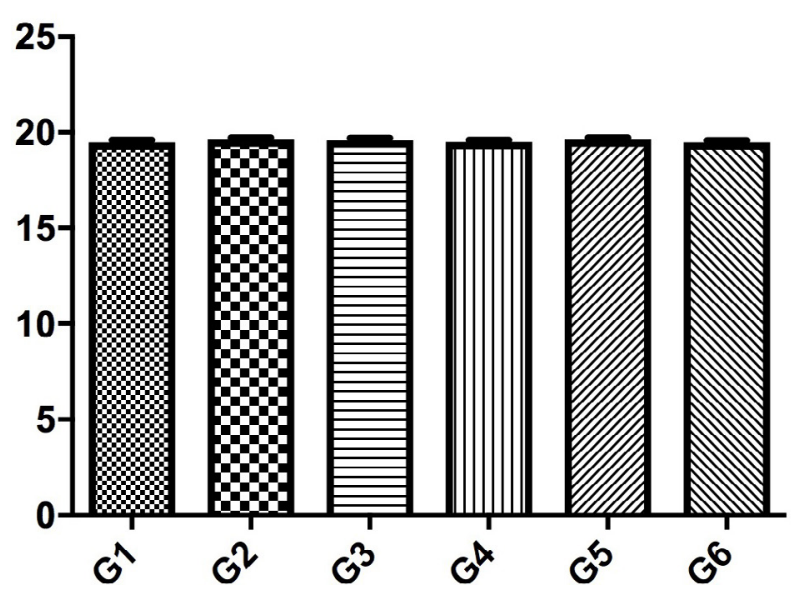

Figure 6 - Leydig cell absolute number (LCAN) of rats in different age groups.

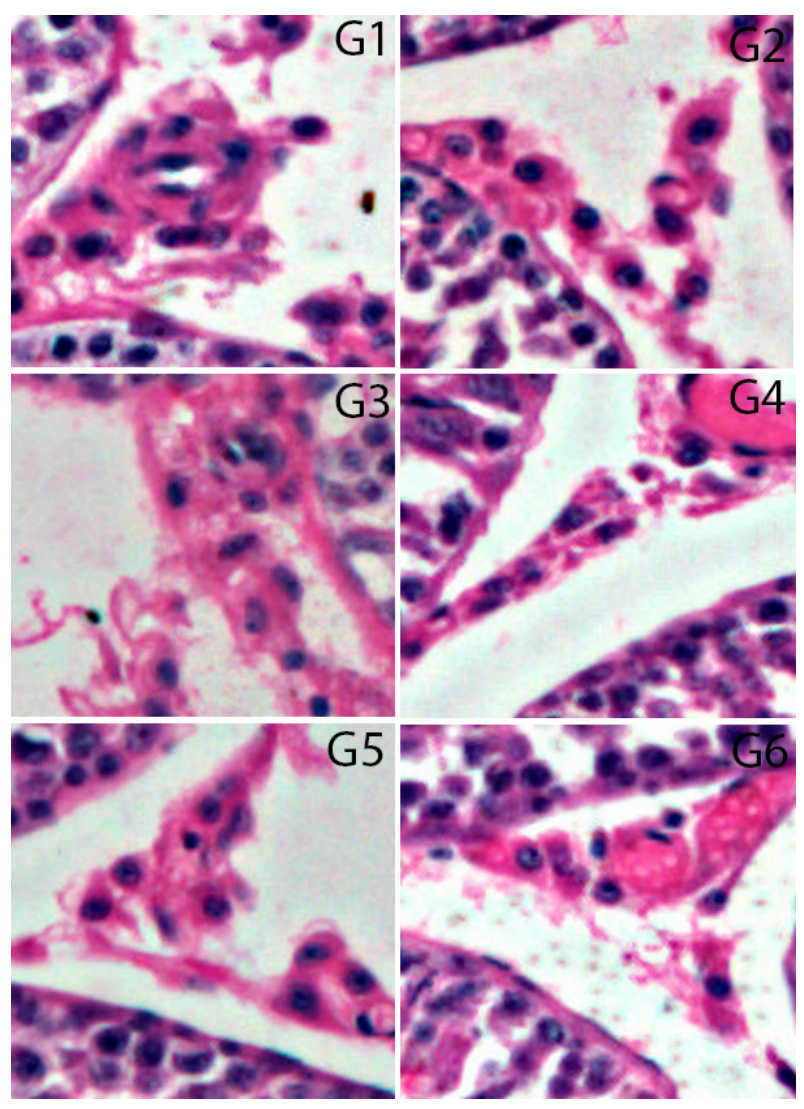

Figure 7 - Interstitial space and Leydig cells of rats in different age groups.

\section{- Discussion}

During testicular development in rodents, LCs divide themselves into fetal and adult types. Fetal-type LCs ensure that the embryo develops as a male and undergo apoptosis after birth ${ }^{12}$. Adult-type LCs, which originate from mesenchymal precursor cells, begin to differentiate 14 days after birth and gradually mature over time ${ }^{13}$.

In rats, adult-type LCs progress through four developmental stages: stem cells until the 14th day after birth, progenitor cells until the 28th day, immature cells until the 56th day, and adult cells, characterized by high hormone production, after the 56 th day ${ }^{14}$. TT serum levels begin to rise on the seventh day after birth, and continue to increase until peaking on the 45th 
day ${ }^{15}$. Rats achieve sexual and reproductive maturity between 40 and 60 days after birth and can live for up to three years. According to an editorial that established equivalencies between the ages of rats and humans, G1 and G6 rats may be considered equivalent in age to 27- and 61-year old humans, respectively ${ }^{16}$.

Zirkin et al. $^{3}$ have shown that serum levels of TT decrease with age in brown rats; this finding was confirmed by Wang et al. ${ }^{17}$ by characterization of intratesticular TT levels in rats at 22 weeks of age.

In the present study, the animals gained weight and grew in length until an age of 18 months, and subsequently decreased. Testicular weight and volume followed an almost identical trend. Comparable decreases in testicular weight have also been observed in rats subjected to chronic stress ${ }^{18}$.

LCNV reduction in elderly rats may be related to chromatin remodeling and telomere shortening, which preclude cells from replicating in old age. Reductions in LCCV and LCTV are possibly associated with hypotrophy of cytoplasmic organelles, which also impairs steroidogenesis. These volumetric reductions predominantly occurred as the animals reached an advanced age, when the negative effects of aging are more evident. In previous stereological studies, it was established that the mean volume of LCs in rats declines with age ${ }^{19}$, and it was shown that the total volume of LCs per testicle and their mean cell volume remain stable until six months of age, with significant reductions observed only in 12- and 19-month old rats ${ }^{20}$.

In this study, LCAN remained constant as the rats aged. Similarly, Wang et al. ${ }^{18}$ demonstrated that the number of LCs in old rats (up to 21 months of age) is not lower than the number of LCs in young rats, and Chen et al. ${ }^{19}$ detected no difference in the number of LCS upon stereological analysis. Thus, the decline in TT levels with age cannot be explained by loss of $\mathrm{LCs}^{17,21}$; this change is the result of LCs dysfunction rather than death ${ }^{7}$.

In old age, adult-type LCs stop dividing. They exhibit defects in steroidogenic pathways and decreased hormone production ${ }^{14,22}$. However, decreases in TT serum levels are not accompanied by changes in luteinizing hormone (LH) serum levels, and must therefore be caused by impaired stimulation of LCs.

LH stimulation increases LC volume and the number of subcellular organelles (endoplasmic reticulum and mitochondria), in contrast deprivation leads to hypotrophic changes in cell structure ${ }^{23}$.

Haolin et al. ${ }^{24}$ conducted a study on in vitro cultures of young and old LCs, which were exposed directly to LH. Even when the LH concentration was maintained at the same level for both cultures, old LCs were unable to produce testosterone at levels comparable to those of young cells. The authors concluded that old LCs have defects in the LH-AMPc signaling cascade, which is involved in testosterone production.

Steroidogenesis by LCs is affected by age for multiple reasons: reduction of cAMP levels, decreased intracellular transport of cholesterol by the steroidogenic acute regulatory (StAR) and translocator (TSPO) proteins, and reduction of the activity of enzymes in mitochondria (CYP11A1, HSD3B) and the smooth endoplasmic reticulum (HSD3B, CYP17A1, HSD17B) ${ }^{25}$.

Many potential causes of senescence in LCs have been proposed, including lesions by free radicals ${ }^{26}$. It could also be speculated that lesions in the cell membrane are the most likely cause of senescence in $\mathrm{LCs}^{14,18}$. Oxidative stress is known to occur during steroidogenesis by LCs, and this may explain the volumetric changes identified in this work. The free radical theory advances the idea that aging is the result of cumulative cellular damage over time ${ }^{27}$. This damage is caused by free radicals produced by catabolic pathways, and increases with age ${ }^{28}$.

The presence of LCs with their 
respective alterations were demonstrated in Figure 7. The most important observation were the hypotrophic findings like reductions in the nuclear volume, cytoplasmic volume and the whole cell. These results are direct involved in the old LCs dysfunction. As these cells lose its volume probably lose the capacity of TT production too.

Hormonal changes during aging are of great clinical and scientific interest. The future offers interesting possibilities of improvement in TT production, such as LCs replacement by stem cell transplantation ${ }^{29}$. New therapies currently under development, such as the use of drugs to stimulate hormone production in LCs, have shown encouraging results ${ }^{30}$. Additional structural and morphometric evaluations are needed to corroborate these findings, followed by assays of oxidative stress.

\section{Conclusions}

Aging in rats was accompanied by hypotrophic changes in Leydig cells. Stereological analyses revealed a reduction in the nuclear, cytoplasmic, and total volumes of these cells. There was no concomitant reduction in cell number.

\section{References}

1. Matsumoto AM. Andropause: clinical implications of the decline in serum testosterone levels with aging in men. J Gerontol A Biol Sci Med Sci. 2002 Feb;57(2):M76-99. PMID: 11818427.

2. Feldman HA, Longcope C, Derby CA, Johannes $C B$, Araujo AB, Coviello AD, Bremner WJ, McKinlay JB. Age trends in the level of serum testosterone and other hormones in middle-aged men: longitudinal results from the Massachusetts Male Aging Study. J Clin Endocrinol Metab. 2002;87(2):589-98. PMID: 11836290.

3. Zirkin BR, Santulli R, Strandberg JD, Wright WW, Ewing LL. Testicular steroidogenesis in the aging brown Norway rat. J Androl.
1993;14(2):118-23. PMID: 8514617.

4. Fawcett DW, Neaves WB, Flores MN. Comparative observations on intertubular lymphatics and the organization of the interstitial tissue of the mammalian testis. Biol Reprod. 1973;9(5):500-32. Available from: PMID: 4203289.

5. Heidelbaugh JJ. Management of erectile dysfunction. Am Fam Physician. 2010 Feb 1;81(3):305-12. PMID: 20112889.

6. Zirkin BR, Chen H. Regulation of Leydig cell steroidogenic function during aging. Biol Reprod. 2000;63:977-81. PMID: 10993816.

7. Chen H, Huhtaniemi I, Zirkin BR. Depletion and repopulation of Leydig cells in the testes of aging brown Norway rats. Endocrinology. 1996 Aug;137(8):3447-52. PMID: 8754773.

8. Noorafshan A. Stereology as a valuable tool in the toolbox of testicular research. Ann Anat. 2014;196(1):57-66. doi: 10.1016/j. aanat.2012.07.008.

9. Sakamoto $H$, Saito $K$, Oohta $M$, Inoue $\mathrm{K}$, Ogawa $\mathrm{Y}$, Yoshida $\mathrm{H}$. Testicular volume measurement: comparison of ultrasonography, orchidometry, and water displacement. Urology. 2007;69(1):152-7. PMID: 17270639.

10.Mattfeldt T, Möbius HJ, Mall G. Orthogonal triplet probes: an efficient method for unbiased estimation of length and surface of objects with unknown orientation in space. J Microsc. 1985 Sep;139(Pt 3):27989. PMID: 3908688.

11.Sterio DC. The unbiased estimation of number and sizes of arbitrary particles using the disector. J Microsc. 1984;134(2):127-36. PMID: 6737468.

12. Huhtaniemi I, Pelliniemi L. Fetal Leydig cells: cellular origin, morphology, life span, and special functional features. Proc Soc Exp Biol Med. 1992;201(2):125-40. PMID: 1409728.

13. Nef S, Shipman T, Parada LF. A molecular basis for estrogen-induced cryptorchidism. Dev Biol. 2000;224(2):354-61. doi: 10.1006/ dbio.2000.9785.

14.Chen $\mathrm{H}, \mathrm{Ge}$ RS, Zirkin BR. Leydig cells: from stem cells to aging. Mol Cell Endocrinol. 2009;306(1-2):9-16. PMID: 19481681.

15. Benton L, Shan L-X, Hardy MP. Differentiation of adult Leydig cells. J Steroid Biochem Mol Biol. 1995;53(1):61-8. PMID: 7626518.

16.Quinn R. Comparing rat's to human's age: How old is my rat in people years? Nutrition. 
2005;21(6):775-7. PMID: 15925305.

17.Wang C, Leung A, Sinha-Hikim AP. Reproductive aging in the male brownNorway rat: a model for the human. Endocrinology. $\quad 1993 ; 133(6): 2773-81$. PMID: 8243304.

18.Wang FF, Wang Q, Chen Y, Lin Q, Gao HB, Zhang $P$. Chronic stress induces ageingassociated degeneration in rat Leydig cells. Asian J Androl. 2012;14(4):643-8. doi: 10.1038/aja.2011.183.

19.Chen $\mathrm{H}$, Hardy MP, Huhtaniemi I, Zirkin BR. Age-related decreased Leydig cell testosterone production in the Brown Norway rat. J Androl. 1994;15(6):551-7. PMID: 7721657.

20.Kim I, Ariyaratne HBS, Mendis-Handagama SMLC. Changes in the testis interstitium of Brown Norway rats with aging and effects of luteinizing and thyroid hormones on the aged testes in enhancing the steroidogenic potential. Biol Reprod. 2002;66(5):1359-66. PMID: 11967198.

21.Ichihara I, Kawamura H, Pelliniemi LJ. Ultrastructure and morphometry of testicular Leydig cells and the interstitial components correlated with testosterone in aging rats. Cell Tissue Res. 1993;271(2):24155. PMID: 8453654.

22.Koeva Y, Bakalska M, Atanassova N, Georgieva K, Davidoff M. Age-related changes in the expression of 11betahydroxysteroid dehydrogenase type 2 in rat Leydig cells. Folia Histochem Cytobiol. 2009;47(2):281-7. doi: 10.2478/v10042009-0021-3.
23.Mendis-Handagama SMLC. Luteinizing hormone on Leydig cell structure and function. Histol Histopathol. 1997;12(3):869-82. PMID: 9225169.

24.Chen H, Hardy MP, Zirkin BR. Age-related decreases in Leydig cell testosterone production are not restored by exposure to LH in vitro. Endocrinology. 2002;143(5):163742. PMID: 11956144.

25. Beattie MC, Adekola L, Papadopoulos V, Chen $H$, Zirkin BR. Leydig cell aging and hypogonadism. Exp Gerontol. 2015;68:8791. PMID: 25700847.

26.Finkel T, Holbrook NJ. Oxidants, oxidative stress and the biology of ageing. Nature. 2000;408(6809):239-47. PMID: 11089981.

27. Harman D. Aging: A Theory Based on Free Radical and Radiation Chemistry. J Gerontol. 1956;11(3):298-300. doi: 10.1093/ geronj/11.3.298.

28.Stadtman ER. Protein oxidation and aging. Science. 1992 Aug 28;257(5074):1220-4. doi: $10.1126 /$ science.1355616.

29.Yang $Y$, Li Z, Wu X, Chen $H$, Xu W, Xiang $Q$, Zhang $Q$, Chen J, Ge RS, Su Z, Huang $Y$. Direct reprogramming of mouse fibroblasts toward Leydig-like cells by defined factors. Stem Cell Reports. 2017;8(1):39-53. doi: 10.1016/j.stemcr.2016.11.010.

30.Andric SA, Janjic MM, Stojkov NJ, Kostic TS. Sildenafil treatment in vivo stimulates Leydig cell steroidogenesis via the cAMP/ cGMP signaling pathway. Am J Physiol Endocrinol Metab. 2010;299(4):E544-50. PMID: 20663985.

\section{Correspondence:}

Bruno Vinicius Duarte Neves

Avenida Sul Brasil, 570/sala 307

89874-000 Maravilha - SC Brasil

Tel.: (55 49)3664-0213

uroneves@gmail.com

Received: June 10, 2017

Review: Aug 14, 2017

Accepted: Sept 16, 2017
Conflict of interest: none

Financial source: none

${ }^{1}$ Research performed at Laboratory of Anatomy and Experimental Surgery, Division of Urology, Department of Surgery, Universidade Federal do Paraná (UFPR), Curitiba-PR, Brazil. Part of Master degree thesis, Postgraduate Program in Surgical Clinic. Tutors: Rogério de Fraga and Fernando Lorenzini. 